\title{
Synthesis and characterization of epoxy/graphite/nano-copper nanocomposite for the fabrication of bipolar plate for PEMFCs
}

\author{
Mahdi Soleimani Alavijeh ${ }^{1}$ (D) Hasan Kefayati ${ }^{1} \cdot$ Ahmad Nozad Golikand $^{2,3} \cdot$ Shahab Shariati $^{1}$
}

Received: 3 November 2018 / Accepted: 4 January 2019 / Published online: 23 January 2019

(c) The Author(s) 2019

\begin{abstract}
In this research, the synthesis of a suitable nanocomposite in terms of properties and economics for use in bipolar plates in proton-exchange membrane fuel cells (PEMFCs) has been carried out successfully. Nowadays, bipolar plates play a significant role in fuel cells which is absolutely important in renewable energy industry. So, epoxy/graphite/nano-copper nanocomposite bipolar plates are prepared by bulk molding compound process. Graphite and nano-copper were added as primary and secondary fillers to the composite, respectively. Epoxy resin was selected since fabrication bulk molding can be done with ease and also because of its lower cost compared to other materials. Although graphite could increase conductive characteristics, it is not sufficient for bipolar plates. Therefore, we boost the conductive properties by increasing nano-copper. Due to the small size of nanoscale copper, it can be well dispersed in polymer and graphite matrix; nano-copper can release conductive properties perfectly throughout the composite. Different percentages of nano-copper, graphite and constant percentage of epoxy are used for this purpose. The electrical resistance, flexural strength, and density of composites were measured according to the applicable standards. The morphology of the prepared plate was studied by scanning electron microscopy (SEM) and X-ray diffraction (XRD) found that fillers disperse well in the matrix. Innovations in this work include improving properties and increasing the efficiency of the nanocomposite by adding metal nanoparticles (copper).
\end{abstract}

Mahdi Soleimani Alavijeh

Mahdi.soleimani108@gmail.com

Hasan Kefayati

Haskefayati@gmail.com

1 Department of Chemistry, Rasht Branch, Islamic Azad University, Rasht 3516-41335, Iran

2 Department of Chemistry, Shahr-e-Qods Branch, Islamic Azad University, Tehran, Iran

3 Material and Nuclear Fuel Cyclic Research School, NSTRI, Tehran, Iran 


\section{Graphical Abstract}

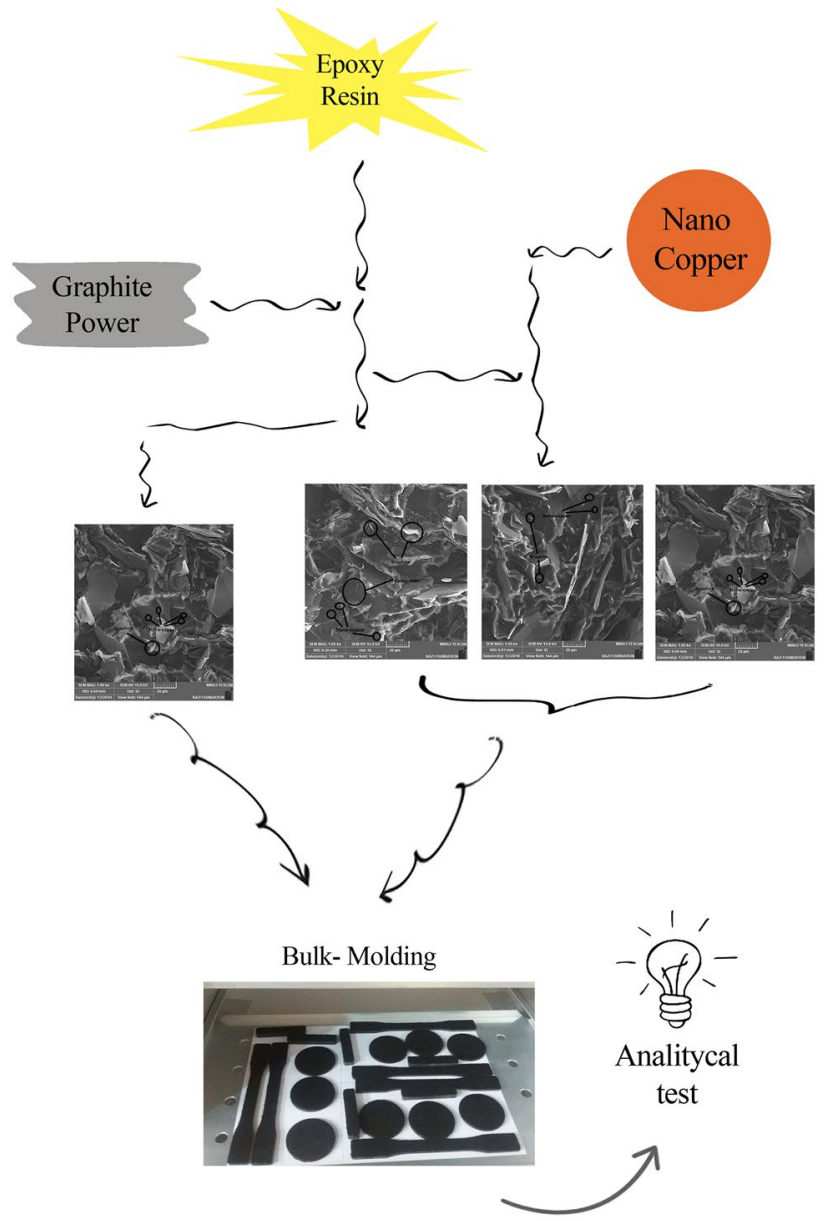

Keywords Bipolar plate $\cdot$ Nanocomposite $\cdot$ Fuel cell $\cdot$ Nano-copper $\cdot$ Graphite

\section{Introduction}

Today, energy and creating new sources of energy has turned into a debatable issue. As we know, the largest source of energy is derived from fossil fuel. This energy is in high demand because of the availability of this kind of energy source and related technologies around the world. On the other hand, consuming this type of energy brings about some drawbacks such as air pollution and global warming, and also it should be considered that this type of energy is not long lasting. So, we have no other way but to replace it with other sources of energy [1,2].

Atomic energy is one of the good and practical options instead of fossil fuel and gradually has been replaced with fossil fuel in a lot of countries. However, atomic energy has got a lot of disadvantages since environmental pollution and disposal of residual material are daunting and the need for special and cost-effective start-up plants is now being abandoned [3]. Among renewable energies such as wind, water, and solar, sunlight energy is more important than others due to constant access and many studies have been done on the production of solar cells from the past, and also it is currently used globally in some parts of the world. But due to the high cost of the required equipment, as well as the need for large space to install them, in addition to continuous and costly maintenance, it has not yet been able to be introduced as a promising source for the replacement of fossil fuels and widely used. Also, in some parts of the world, because of the atmospheric conditions of that area or the angle of the sun's radiation, it is virtually impossible to use this source of energy [4, 5]. But proton-exchanging fuel cells have been emerging for some time now as a tempting substitute for fossil fuels, especially in fuel for vehicles [6]. These devices, such as a battery, convert chemical energy directly into electrical energy without creating any environmental pollution. Moreover, due to high efficiency and elimination 
of noise pollution, interest in using these new sources of energy is increasing. Fuel cells play an important role in the economy of this century and probably in the future. It is anticipated that the development and expansion of reliable and economical fuel cells will launch the era of hydrogen [7]. The proton-exchange fuel cell system is an energy system that can convert hydrogen and oxygen (air) to electricity and produce water as the only peripheral product. So much of the environmental stress is considered. It is also used for all human societies because of its low cost. Considering all the benefits and applications of these cells, due to the presence of some of the existing barriers, such as reliability, stability, weight, and price, the use of these cells is still in research and demonstration and their commercialization has been delayed. Today, many studies are underway to remove existing barriers that promise to bring this energy to live in the near future. The highest weight of a fuel cell (about $80 \%$ ) is made up of bipolar plates, which is about $38 \%$ of the total cost of the cells. Electrodes cost $32 \%$, membranes $12 \%$, and electrolytes $11 \%$ of the total fuel cell price. Considering that the bulk density of the fuel cells is the highest in bipolar plates, it can be assumed that the most important components of these cells are the bipolar plates and should be the most efficient with the least weight and cost. That is why most recent research on fuel cells focuses on optimizing these fuel cell components and continues. So far, a lot of materials have been proposed for these components such as stainless steel, titanium and graphite composites. Graphite due to its electrical conductivity and corrosion resistance is a reference material for durability and performance. But its porous structure makes it fragile and also allows for the penetration of gases after use. Corrective processes, such as a combination with a saturated resin, are used to fill the holes. But this will increase the price. A solution has been proposed to solve these problems, and it is the use of polymer nanocomposites that combine the mechanical properties and processability of polymers with the conductivity properties of carbon fillers. Nanocomposite conducting plates (CPs) are widely used alternative materials for bipolar plates in proton-exchange membrane fuel cells (PEMFCs) due to good corrosion resistance, good electrical and thermal conductivity, low cost, easy fabrication, and suitable weight instead of metal and graphite alone. Metals' bipolar plates have benefits such as good electrical and thermal conductivity, ease of machinery, and suitable weight. The main disadvantage of metals, on the other hand, is their high corrosion current density. Also, graphite bipolar plates have good electrical and thermal conductivity and low-cost characterization. Due to their low mechanical strength, the thickness of the plates cannot be reduced, leading to their higher weights [8].

According to the criteria of the American Department of Energy (DOE), the bipolar plates should meet the requirements shown in Table 1.
Table 1 US DOE technical targets for composite bipolar plates

\begin{tabular}{ll}
\hline Property & Value \\
\hline Weight & $<0.4 \mathrm{~kg} \mathrm{~kW}^{-1}$ \\
Flexural strength & $>25 \mathrm{MPa}$ \\
Flexibility & $3-5 \%$ deflection at mid-span \\
Electrical conductivity & $>100 \mathrm{~S} \mathrm{~cm}^{-1}$ \\
Thermal conductivity & $>10 \mathrm{~W}(\mathrm{mK})^{-1}$ \\
Gas permeability & $<2 \times 10-6 \mathrm{~cm}^{3} \mathrm{~cm}^{-2} \mathrm{~s}^{-1}$ at \\
Corrosion resistance & $80{ }^{\circ} \mathrm{C} \mathrm{and} 3 \mathrm{~atm}^{-2}$ \\
\hline
\end{tabular}

Recently, many investigations have shown that composite CPs including polymers (thermoplastic and thermoset) and graphite may possess good characterizations. Polymers used for this purpose are vinyl ester [9, 30], epoxy [10, 25, 26], polypropylene [11, 22, 27], phenolic resin [12, 29], polyvinylidene fluoride $[13,28]$, polyphenylene sulfide [14], polymethyl methacrylate, polyurethane [15], etc. Also, many metals are used as bipolar plates such as stainless steel [16, 17], silver [18], gold, lead, aluminum [19, 31], titanium [20], and chromium $[21,24]$. Because of their enhanced strength, bipolar plates are prepared from composites of metal and graphite such as the pairs of stainless steel-graphite [22, 23] and chromium-carbon [24]. These articles reported increased performance of bipolar plate.

In this work, we prepared nanocomposites including polymer, graphite, and nano-metal with different percentages of metal. It is expected that nano-copper will be loaded into cavities inside the graphite. In this case, in addition to increasing its conductivity, it increases the strength and mechanical properties of the composite. According to this forecast, polymer-graphite nanocomposites can be obtained that combine the properties of metals, graphite, and polymer. The epoxy resin was used as a polymer matrix because of its low cost and simple bulk molding while nano-copper was used as the metal considering its high electrical and thermal conductivity. The nanocomposite was prepared using bulk molding as it is a simple method for the preparation of bipolar plates. Next, the flexural strength, resistance electrical, density, weight, and morphology of the prepared nanocomposites were compared.

\section{Experimental}

\section{Materials}

The natural flake graphite, with a purity of $99.9 \%$ was obtained from Qingdao Guyu Graphite Company, China. The epoxy resin (EP) was a bisphenol A-based epoxy resin, with a viscosity of $6 \mathrm{P}$ obtained from US Composites. The 
Table 2 Percentage of materials in epoxy/Gr/Cu nanocomposites

\begin{tabular}{lllll}
\hline Epoxy/graphite/Cu nanocomposite & & \\
\hline & $\begin{array}{l}\text { Sample 1 } \\
(\%)\end{array}$ & $\begin{array}{l}\text { Sample 2 } \\
(\%)\end{array}$ & $\begin{array}{l}\text { Sample 3 } \\
(\%)\end{array}$ & Sample 4 (\%) \\
\hline $\begin{array}{l}\text { Epoxy } \\
\text { resin }\end{array}$ & 77.5 & 77.5 & 77.5 & 77.5 \\
Graphite & 22.5 & 21 & 19.5 & 17.5 \\
Nano-Cu & 0 & 1.5 & 3 & 5 \\
\hline
\end{tabular}

Table 3 Electrical resistance of the composite bipolar plates

\begin{tabular}{lllll}
\hline Sample number & 1 & 2 & 3 & 4 \\
\hline Electrical resistance $(\mathrm{m} \Omega / \mathrm{cm})$ & 7400 & 7820 & 7816 & 1202 \\
\hline
\end{tabular}

curing temperature of the epoxy recommended by the manufacturer was $80^{\circ} \mathrm{C}$. The curing agent, 4-aminophenylsulphone, was purchased from New Jersey, USA. This agent was a diamine type (tetra-functional) to facilitate rapid and dense cross-linking in the epoxy resin. Nano-powder copper was obtained from Shenzhen Junye Nano-Material Co., Ltd with $25-50 \mathrm{~nm}$ particle size.

\section{Preparation of the nanocomposite materials}

The bulk molding compounds were prepared by mixing the resin, graphite, nano-copper powder, and hardener in a vessel of polypropylene (PP) for $2 \mathrm{~h}$, as shown in Table 2 . All numbers are reported based on weight percentages.

Then the compounds were molded at ambient temperature for 5 min and bulk molded in the RTV silicone mold. Finally, these molds were cured in an oven at $80^{\circ} \mathrm{C}$ for $24 \mathrm{~h}$. When mixing, it must be ensured that the stirring speed is such as to prevent the formation of bubbles in the mixture. Also at the time of molding, creation of bubbles in the nanocomposite should be prevented and gentle molding has to be done. Graphite and nano-copper should be mixed together before being added to the resin. This will result in a more uniform mix of fillers in the polymer matrix. The hardener should be added after 100 min of mixing the previous material and is only combined for $20 \mathrm{~min}$. Finally, it is noted that stainless steel blades are used for mixing.

\section{Characterization}

The electrical resistance (Table 3) of the composite bipolar plate was measured according to ASTM C611.

The flexural strength of composite bipolar plate was tested in accordance with ASTM D790-15 with a universal testing machine (Instron WDW-E200). The specimen was $60 \mathrm{~mm}$ in length, $5 \mathrm{~mm}$ in width, and $3 \mathrm{~mm}$ in thickness.
Table 4 Flexural strength of the composite bipolar plates

\begin{tabular}{lllll}
\hline Sample number & 1 & 2 & 3 & 4 \\
\hline Flexural strength (MPa) & 36.15 & 36.88 & 40.04 & 40.34 \\
\hline
\end{tabular}

Table 5 Density of the composite bipolar plates

\begin{tabular}{lllll}
\hline Sample number & 1 & 2 & 3 & 4 \\
\hline Density $\left(\mathrm{g} / \mathrm{cm}^{3}\right)$ & 1.282 & 1.242 & 1.274 & 1.329 \\
\hline
\end{tabular}

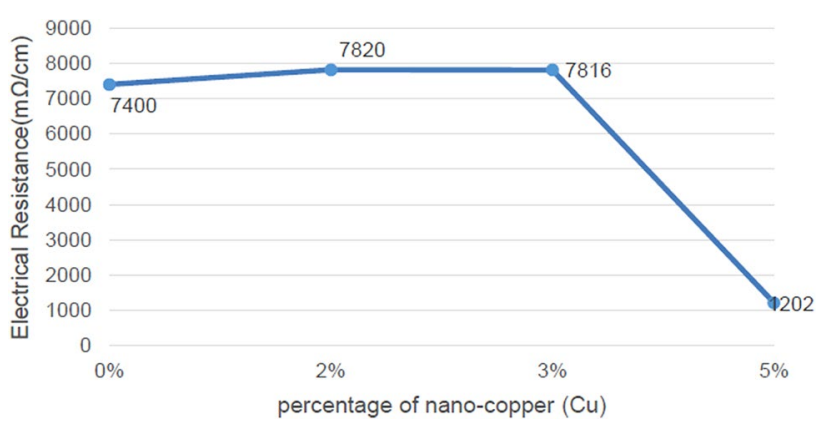

Fig. 1 The comparison of the electrical resistance of nanocomposite epoxy/graphite/nano-copper $(\mathrm{Ep} / \mathrm{Gr} / \mathrm{Cu})$

The supporting span is $40 \mathrm{~mm}$ at a constant crosshead speed of $0.5 \mathrm{~mm} / \mathrm{min}$. Table 4 summarizes the values of flexural strength for nanocomposites.

The density of samples was measured according to ASTM D792-13A and reported as the average of three weights per sample and shown in Table 5.

The section morphologies of the composite bipolar plate were observed on a JSM-6700F type scanning electron microscope (SEM). X-ray diffraction (XRD) of the composites was carried out by a Rigaku X-ray with $\mathrm{Cu}$ Ka radiation applied at $40 \mathrm{kV}$.

\section{Results and discussion}

In this study, the resin epoxy and hardener contents were constant while graphite and nano-copper contents were varied. Figure 1 shows that electrical resistance decreased by increasing in the nano-copper content. This decrease is evident from 3 to 5\% of nano-copper and reached 1200 $(\mathrm{m} \Omega / \mathrm{cm})$ while the electrical resistance of the composite of epoxy/graphite was determined to be $7400(\mathrm{~m} \Omega / \mathrm{cm})$. This result shows that the addition of nano-copper to the composite of epoxy/graphite may enhance the electrical conductivity of this composite. When the particle size of copper is in nanoscale, these particles could have good distribution and cause more passing of ions into the composite. The 
nanoparticles of copper can fill the holes in the graphite and thereby increase the conductivity of the graphite in the matrix. Also, the increase in surface area of nanoparticle results in using less amount of metal and increases corrosion resistance. As shown in Fig. 1, by increasing the number of copper nanoparticles from 3 to 5, electrical resistance is significantly reduced which represents more appropriate distribution and filling more empty spaces by nano-copper. In other words, with the increase of nano-copper, the conductivity and flow of electrical ions in nanocomposites have increased and more pathways have been created to cross them into nanocomposites.

The flexural strength of this composite was increased with the addition of nano-copper. Since epoxy resin can increase the flexural strength of composites containing graphite, it was used as the matrix in the present work. However, this polymer has insulating properties and decreases the electrical conductivity in bipolar plate. Thus, when nano-copper was added to the composite, the electrical conductivity and flexural strength are increased. If beyond $5 \mathrm{wt} \%$ of nanocopper is added and mixed by composite bulk, the electrical conductivity and flexural strength amounts are decreased. Figure 2 presents the flexural strength increase with an increase in nano-copper content. However, metals have physical properties that make them suitable for gaining the desired final characterization of the nanocomposite. For example, nano-metals could fill the porosity of composite to obtain a monotonous texture. In addition, the weak corrosion resistance of the metal is a large disadvantage; however, adding metals with small dimensions (nano-copper) in the composite could be beneficial because corrosion can be ignored for a large surface contact that can increase electrical conductivity. Figure 2 shows that with the increasing nano-copper percentage from 1.5 to 3 , the flexural strength has increased significantly, while this increase of flexural strength is not significant by increasing the nano-copper content from 3 to 5\%. According to Figs. 1 and 2, it can be concluded that the percentage of nano-copper is suitable for the nanocomposite of about $5 \%$.

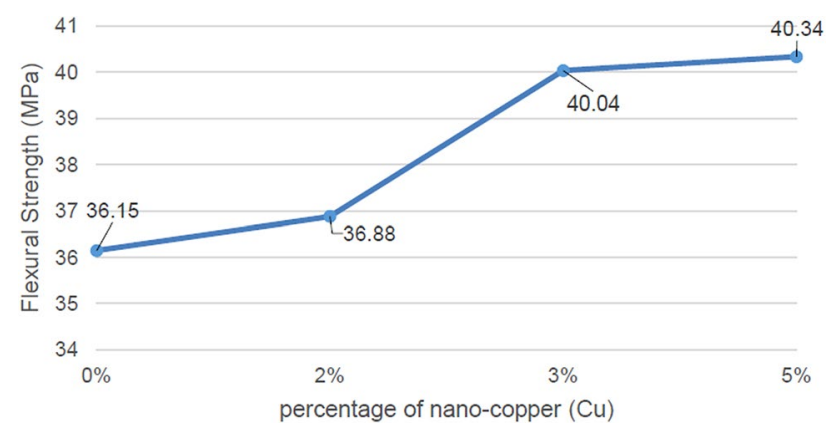

Fig. 2 The comparison of flexural strength of nanocomposite epoxy/ graphite/nano-copper $(\mathrm{Ep} / \mathrm{Gr} / \mathrm{Cu})$
The flexural strength of these composites, as shown in Knibbs' equation [17], is related to their porosity and the particle size of fillers:

$\sigma=k D^{1 / 2} e^{b p}$

where $k$ and $b$ are empirical constants; $D$ and $P$ are the maximum diameter of grains and porosity, respectively; and $\sigma$ is the flexural strength. Equation 1 shows the relationship between flexural strength and porosity at the same $D$. This equation shows that by increasing the size of the holes and nanoparticles, the flexural strength decreases.

Figure 3 illustrates an SEM image of the composite, where graphite and nanoparticles are well dispersed in the polymer matrix. The morphology shown in this figure is a continuous matrix without any pores that results in the increase of flexural strength and electrical conductivity. It can be seen in Fig. 3a that there is not any nano-copper, but there are graphite and epoxy as a polymer. Therefore, the porosity of this composite is high and is quite clear. It also clearly shows the structure of a layer of graphite. When nano-copper is added as a second filler, the cavities are reduced resulting in a denser texture. This can be clearly seen in Fig. 3b-d. The amount of nano-copper is $1.5,3$, and 5 , respectively, in the forms $\mathrm{B}, \mathrm{C}$ and $\mathrm{D}$. By increasing the amount of nano-copper, the texture of nanocomposite becomes denser and more holes are filled. Consequently, in Fig. 3d, which nano-copper amount is $5 \%$, the highest density than other shapes can be seen. This high density increases the flexural strength and electrical conductivity and, therefore, increases the quality of the nanocomposite for use in bipolar plates. Due to the size of the copper nanometer, this dispersion and density have been created more favorably and there are fewer empty spaces in nanocomposite texture.

This continuous matrix can increase the density of the composite. Figure 4 shows that at low percentages of nano-copper, density does not change toward epoxy/ graphite composite. When copper content reaches $5 \%$, an increase in density to $1.329 \mathrm{~g} \mathrm{~cm}^{-3}$ is also seen. This is the highest density in nanocomposites synthesized with nanocopper. As a result, a larger number of pores are filled by the addition of copper, producing a heavier matrix. This increase in the density could help in the improvement of flexural strength.

The X-ray pattern of composites is shown in Fig. 5. The nano-copper exhibits three sharp diffraction peaks at 44, 51 and 74 . The pure graphite has a sharp diffraction peak at $2 \theta=26$. The peaks at 44,54 and 77 are epoxy resins. All the above peaks of graphite, nano-copper and epoxy are present in nanocomposites of epoxy/graphite/nano-Cu confirm the formation of nanocomposites. This could be due to the intercalation and uniform dispersion of nano- $\mathrm{Cu}$ and graphite within the epoxy matrix. 


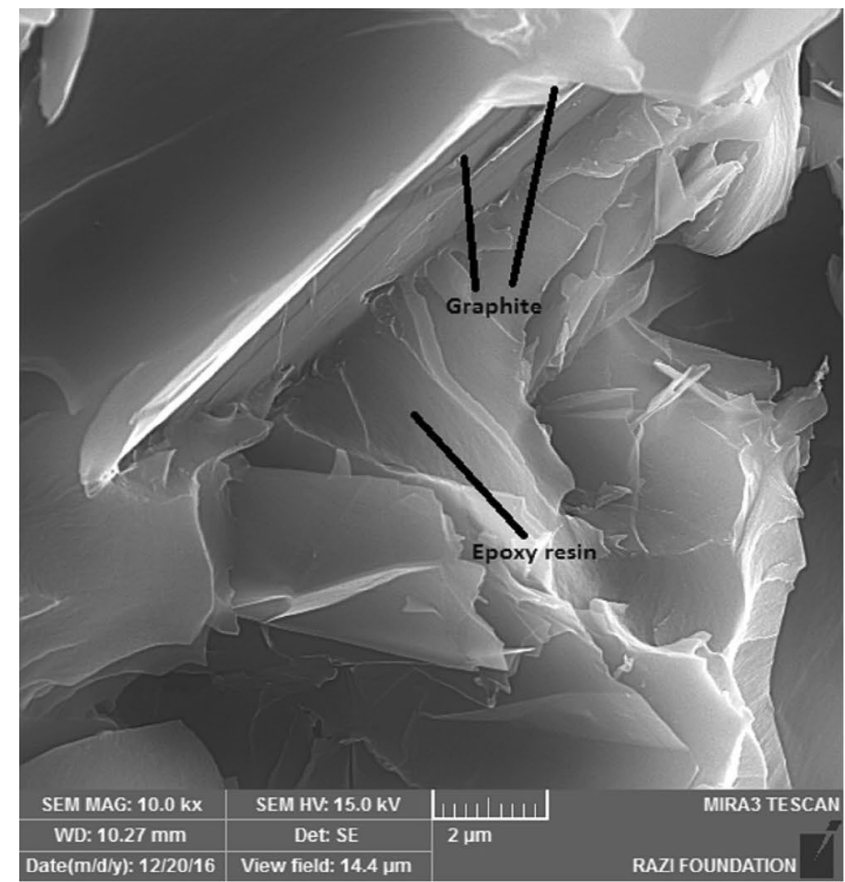

A

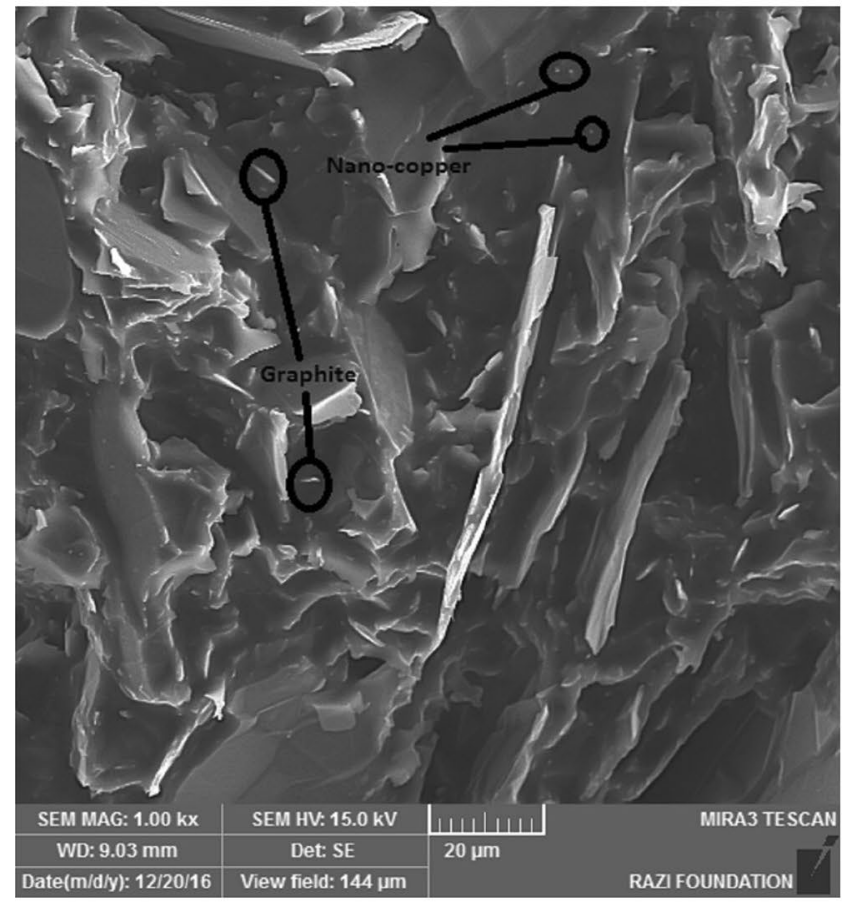

C

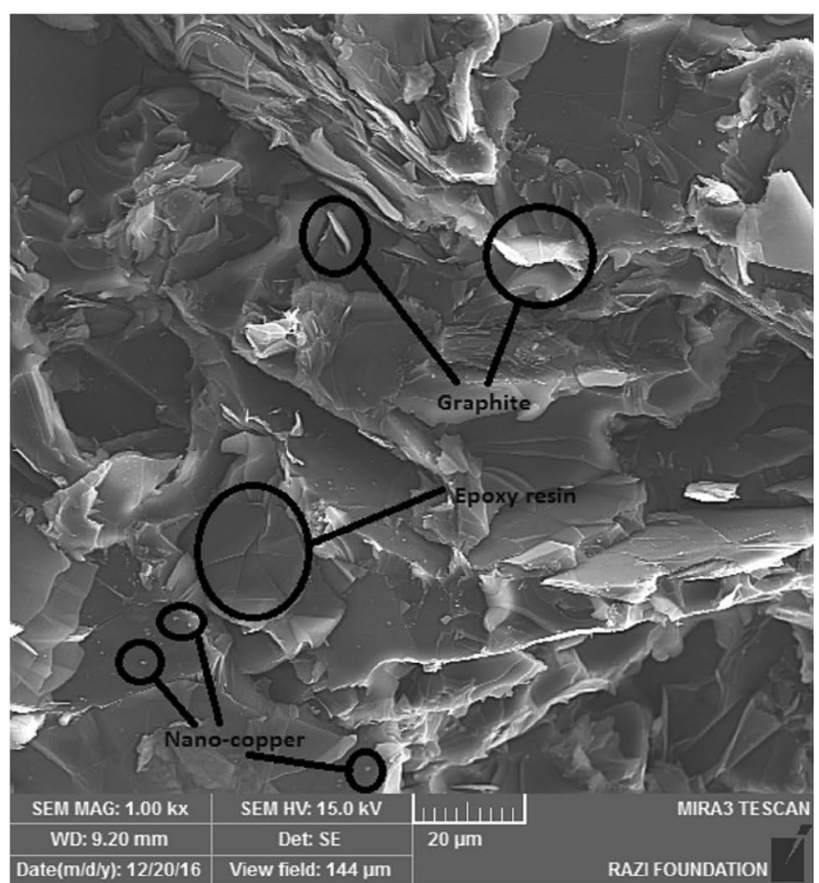

B

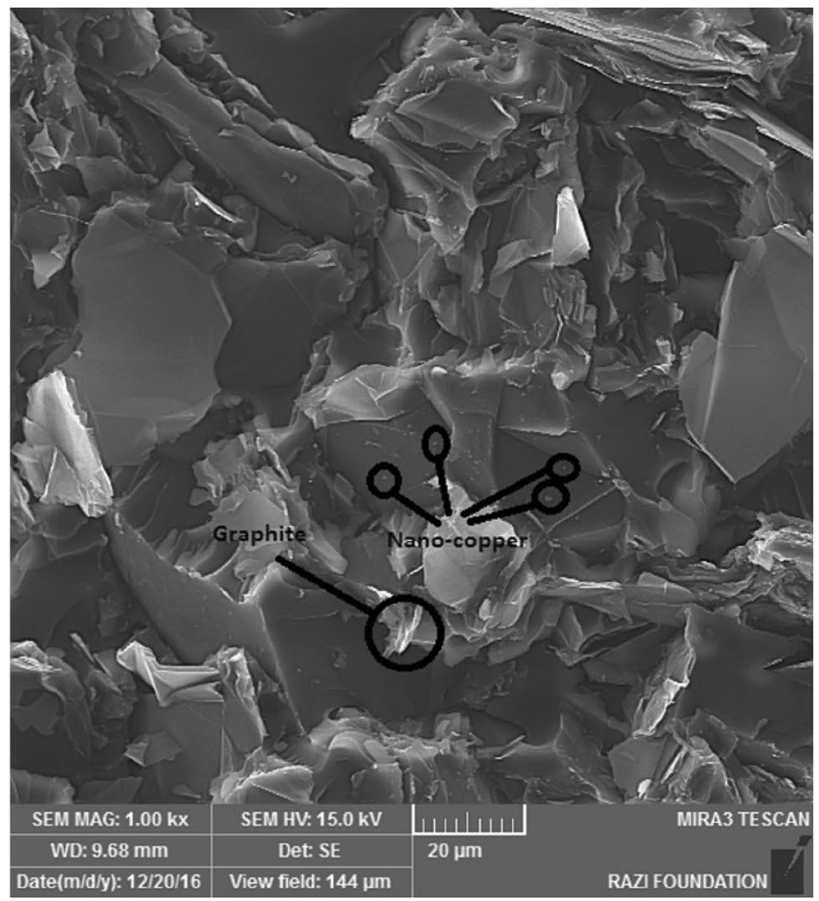

D

Fig. 3 SEM of nanocomposites: epoxy/grand epoxy/Gr/Cu in a-d, respectively

Figures 1 and 2 show that the increase in the percentage of nano-copper up to 5\% resulted in a significant reduction of electrical resistance and also an appropriate increase in the flexural strength of the composite. However, according to Fig. 4, the composite density increases. Therefore, by increasing the percentage of nano-copper and filling the porous in the composite, the electrical conductivity of the bipolar plates can be increased appropriately. 


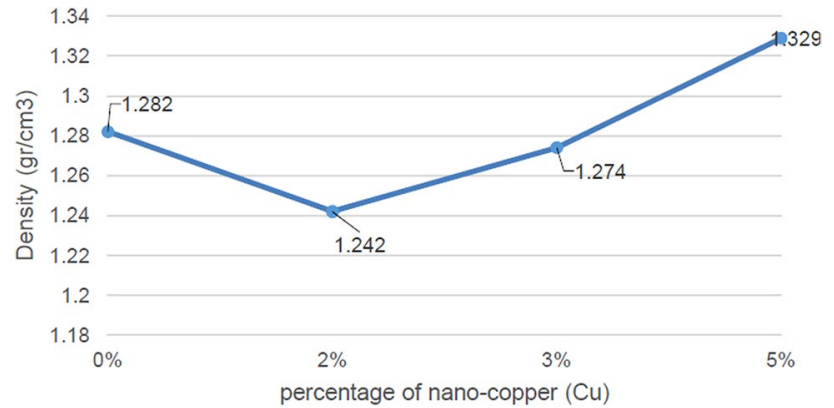

Fig. 4 The comparison of density of nanocomposite epoxy/graphite/ nano-copper $(\mathrm{Ep} / \mathrm{Gr} / \mathrm{Cu})$

These data show that nanocomposite of epoxy/graphite/ nano-copper can be used as a bipolar plate in full cell by little correction. The presence of copper metal nanoparticles along with graphite reduces electrical resistance and increases nanocomposite density. Also, the presence of epoxy polymer in this nanocomposite has increased the flexural strength of the nanocomposite.

\section{Conclusion}

Epoxy/graphite/nano-copper nanocomposites can be considered as suitable for use in the production of bipolar plates in PEMFCs because it has both the mechanical properties of the epoxy polymer and the electrical conductivity of the graphite/nano-copper. In this work, we first used copper nanoparticles with graphite as filler in epoxy. We could greatly improve the properties of the nanocomposite produced for use in bipolar plates. Also from the economic point of view, raw materials used are very affordable and has the possibility of commercialization. The flexural strength of the composite plate was increased by a decrease in graphite and an increase in the nano-copper content of the composites. On the other hand, the electrical resistance was decreased by decreasing graphite and increasing nano-copper contents. The greatest improvement is the time when $5 \%$ of nano-copper is added to the nanocomposite. The flexural strength is controlled by the morphology and density of nanocomposites. The higher the density, the greater the flexural strength. The addition of metal nanoparticle to epoxy/graphite composites provided nanocomposites that are used as bipolar plates in PEMFC.
Fig. 5 The X-ray pattern of epoxy/graphite/nano-Cu at percentage of nano- $\mathrm{Cu}$ and graphite and XRD of nano-copper and graphite (as above)
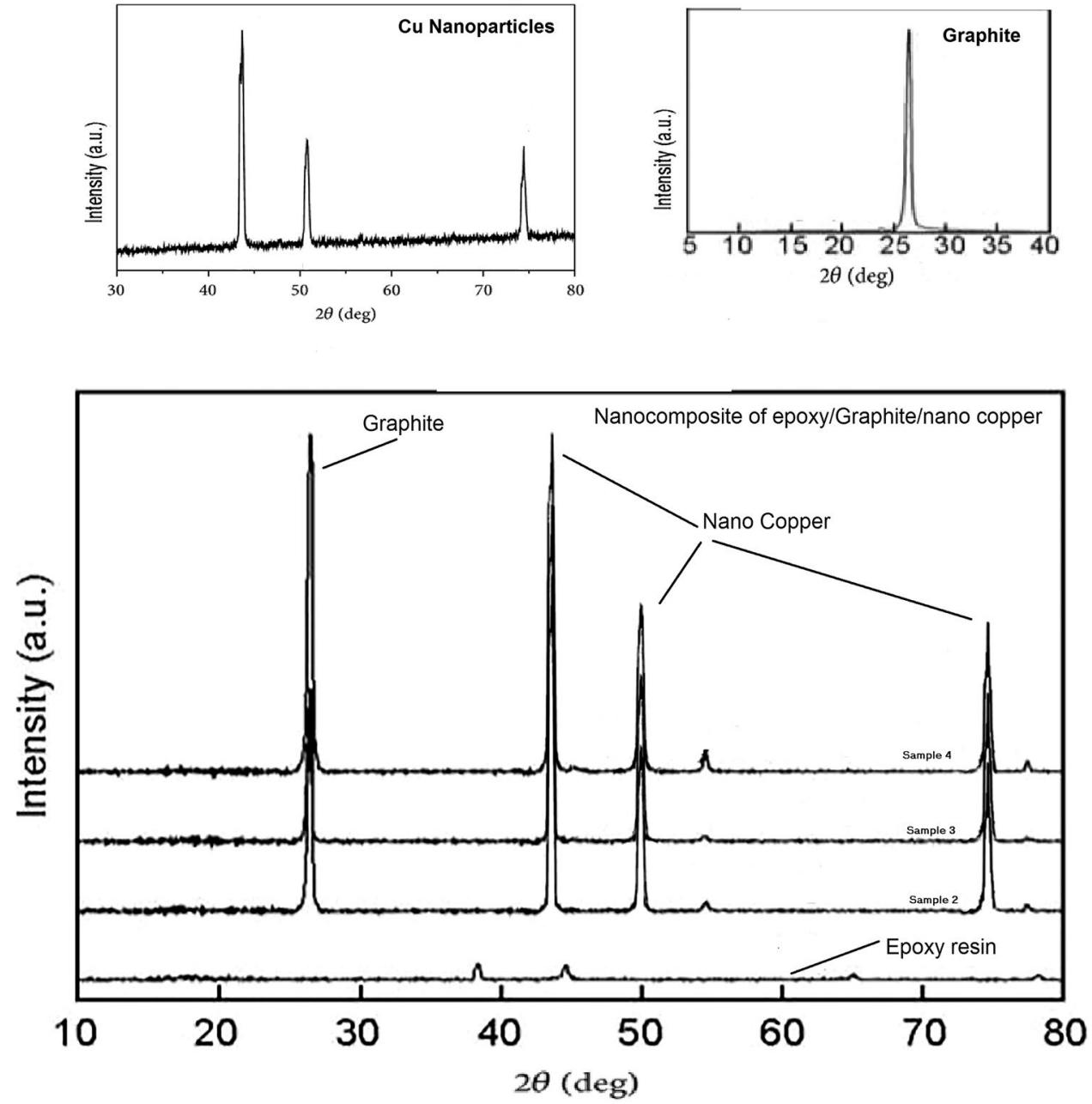
Acknowledgements The authors are grateful to the Islamic Azad University of Rasht Branch for supporting this work and Razi Applied Science Foundation for cooperation to achieve the results.

Open Access This article is distributed under the terms of the Creative Commons Attribution 4.0 International License (http://creativeco mmons.org/licenses/by/4.0/), which permits unrestricted use, distribution, and reproduction in any medium, provided you give appropriate credit to the original author(s) and the source, provide a link to the Creative Commons license, and indicate if changes were made.

\section{References}

1. Panwar, N.L., Kaushik, S.C., Kothari, S.: Role of renewable energy sources in environmental protection. Renew. Sustain. Energy Rev. 15, 1513-1524 (2011)

2. John, A.T.: A realizable renewable energy future. Renewable and non-renewable energy consumption anld economic growth in emerging economies: Evidence from bootstrap panel causality. Renew. Energy 111, 757-763 (2017)

3. Mathiesen, B.V., Lund, H., Connolly, D., Wenzel, H., Østergaard, P.A., Möller, B., Nielsen, S., Ridjan, I., Karnøe, P., Sperling, K., Hvelplund, F.K.: Smart energy systems for coherent $100 \%$ renewable energy and transport solutions. Appl. Energy 145, 139-154 (2015)

4. Shafiee, S., Topal, E.: When will fossil fuel reserves be diminished? Energy Policy 37, 181-189 (2009)

5. Dimitriou, P., Tsujimura, T.: A review of hydrogen as a compression ignition engine fuel. Int. J. Hydrogen Energy 42, 24470-24486 (2017)

6. Edwards, P.P., Kuznetsov, V.L., David, W.I.F., Brandon, N.P.: Hydrogen and fuel cells: towards a sustainable energy future. Energy Policy 36, 4356-4362 (2008)

7. Agbossou, K., Chahine, R., Hamelin, J., Laurencelle, F., Anouar, A., St-Arnaud, J.M., Bose, T.K.: Renewable energy systems based on hydrogen for remote applications. J. Power Sources 96, 168-172 (2001)

8. Magdalena, M., Veziroglu, T.N.: The properties of hydrogen as fuel tomorrow in a sustainable energy system for a cleaner planet. Int. J. Hydrogen Energy 30, 795-802 (2005)

9. Shu, H.L., Min, C.H., Chuan, Y.Y., Chen, C.M., Shuo, J.L., Ay, S., Ming, C.T., Ming, Y.Y., Po, L.L.: Novel functionalized carbon nanotubes as cross-links reinforced vinyl ester/nanocomposite bipolar plates for polymer electrolyte membrane fuel cells. J. Power Sources 195, 7808-7817 (2010)

10. Chen, H., Liu, H., Yang, L., Li, J., Yang, L.I.: Study on the preparation and properties of novolac epoxy/graphite composite bipolar plate for PEMFC. Int. J. Hydrogen Energy 35, 3105-3109 (2010)

11. Liao, S.-H., Yen, C.-Y., Weng, C.-C., Lin, Y.-F., Ma, C.-C.M., Yeng, C.-H., Tsai, M.-C., Hsiao, M.-C., Lee, S.-J., Xio, X.-F., Hsiao, Y.-H.: Preparation and properties of carbon nanotube/polypropylene nanocomposite bipolar plates for polymer electrolyte membrane fuel cells. J. Power Sources 185, 1225-1232 (2008)

12. Taherian, R., Golikand, A.N., Hadianfard, M.J.: Preparation and properties of a phenolic/graphite nanocomposite bipolar plate for proton exchange membrane fuel cell. ECS J. Solid State Sci. Technol. 1, 39-46 (2012)

13. Antunes, R.A., De-Oliveira, M.C.L.: Investigation on the corrosion resistance of carbon black-graphite-poly (vinylidene fluoride) composite bipolar plates for polymer electrolyte membrane fuel cells. Int. J. Hydrogen Energy 36, 12474-12485 (2011)

14. Kim, N.H., Kuila, T., Kim, K.M., Nahm, S.H., Lee, J.H., Nam, H.: Material selection windows for hybrid carbons/poly (phenylene sulfide) composite for bipolar plates of the fuel cell. Polym. Test. 31, 537-545 (2012)
15. Phuttachart, T., Kreua-Ongarjnukool, T., Yeetsorn, N., Phongaksorn, Y.: PMMA/PU/CB composite bipolar plate for direct methanol fuel cell. Energy Procedia 52, 516-524 (2014)

16. Mele, C., Bozzini, B.: Localised corrosion processes of austenitic stainless steel bipolar plates for polymer electrolyte membrane fuel cells. J. Power Sources 195, 3590-3596 (2010)

17. Wind, J., Spah, R., Kaiser, W., Bohm, G.: Metallic bipolar plates for PEM fuel cells. J. Power Sources 105, 256-260 (2002)

18. Min, Z., Lin, H., Guoqiang, L., Zhigang, S.: Honeycomb-like nanocomposite Ti-Ag-N films prepared by pulsed bias arc ion plating on titanium as bipolar plates for unitized regenerative fuel cells. J. Power Sources 198, 196-202 (2012)

19. Borrell, A., Torrecillas, R., Rocha, V.G., Fernández, A.: Aluminacarbon nanofibers nanocomposites obtained by spark plasma sintering for proton exchange membrane fuel cell bipolar plates. Fuel Cell 12, 599-605 (2011)

20. Park, Y.-C., Lee, S.-H., Kim, S.-K., Lim, S., Jung, D.-H., Lee, D.-Y., Choi, S.-Y., Ji, H., Peck, D.-H.: Performance and long-term stability of Ti metal and stainless steels as a metal bipolar plate for a direct methanol fuel cell. Int. J. Hydrogen Energy 35, 4320-4328 (2010)

21. Barranco, J., Barreras, F., Lozano, A., Lopez, A.M., Roda, V., Martin, J., Maza, M., Fuentes, G., Almandoz, E.: Cr and $\mathrm{Zr} / \mathrm{Cr}$ nitride CAE-PVD coated aluminum bipolar plates for polymer electrolyte membrane fuel cells. Int. J. Hydrogen Energy 35, 11489-11498 (2010)

22. Liao, S.-H., Weng, C.-C., Yen, C.-Y., Hsiao, M.-C., Ma, M., Tsai, M.-C., Su, A., Yen, M.-Y., Lin, Y.-F., Lio, P.-L.: Preparation and properties of functionalized multiwalled carbon nanotubes/polypropylene nanocomposite bipolar plates for polymer electrolyte membrane fuel cells. J. Power Sources 195, 263-270 (2010)

23. Matsuura, T., Kato, M., Hori, M.: Study on the metallic bipolar plate for proton exchange membrane fuel cell. J. Power Sources 161, 74-78 (2006)

24. Nygran, K., Andersson, M., Hogstrom, J., Fredriksson, W., Edstrom, K., Nyholm, L., Jansson, U.: Influence of deposition temperature and amorphous carbon on microstructure and oxidation resistance of magnetron sputtered nanocomposite Cr C films. Appl. Surf. Sci. 305, 143-153 (2014)

25. Du, C., Ming, P., Hou, M., Fu, J., Shen, Q., Liang, D., Fu, Y., Luo, X., Shao, Z., Yi, B.: Preparation and properties of thin epoxy/ compressed expanded graphite composite bipolar plates for proton exchange membrane fuel cells. J. Power Sources 195, 794-800 (2010)

26. Kuan, H.-C., Ma, M.: Preparation, electrical, mechanical and thermal properties of a composite bipolar plate for a fuel cell. J. Power Sources 134, 7-17 (2004)

27. Sulong, A.B., Ramli, M.I., Hau, S.L., Sahari, J., Muhamad, N., Suherman, H.: Rheological and mechanical properties of carbon nanotube/Graphite/SS316L/polypropylene nanocomposite for a conductive polymer composite. Composites 50, 54-61 (2013)

28. Li, Y., Shimizu, H.: Conductive PVDF/PA6/CNTs nanocomposites fabricated by dual formation of continuous and nanodispersion structures. Macromolecules 14, 5339-5344 (2008)

29. Kakati, B.K., Sathiyamoorthy, D., Verma, A.: Electrochemical and mechanical behavior of carbon composite bipolar plate for fuel cell. Int. J. Hydrog. Energy 35, 4185-4194 (2010)

30. Liao, S.-H., Hung, C.-H., Ma, M.: Preparation and properties of carbon nanotube-reinforced vinyl ester/nanocomposite bipolar plates for polymer electrolyte membrane fuel cells. J. Power Sources 176, 175-182 (2008)

31. Tawfik, H., Hung, Y., Mahajan, D.: Metal bipolar plates for PEM fuel cell-A review. J. Power Sources 163, 755-767 (2007)

Publisher's Note Springer Nature remains neutral with regard to jurisdictional claims in published maps and institutional affiliations. 